\title{
Liability Procedures and Alternatives in the Federal Republic of Germany
}

\author{
by Werner Pfennigstorf *
}

\section{Summary of Contents}

1. Introduction

2. Sources of compensation

2.1. Overview

2.2. Social security

2.3. Liability insurance

3. Coordination and settlement

3.1. Overview

3.2. Subrogation

4. Litigation

4.1. Access to courts

4.2. Courts and their procedure

4.3. Data on litigation

5. Costs

5.1. Overview

5.2. Data on accidents

5.3. Data on accident costs and compensation

5.4. Data on liability insurance claims

5.5. Components of tort system costs

5.6. Total system costs

6. Indicators of Dynamic and of Potential Change

6.1. Overview

6.2. No-fault compensation through social security

6.3. Expansion of liability under tort law

6.4. Changes in procedures

6.5. Expansion of liability insurance coverage

6.6. Compensation funds

6.7. Criticism and reform proposals

6.8. Public opinions, attitudes, and other indicators of acceptance or impending change

\footnotetext{
* The following is a condensed and revised version of a preliminary report prepared in 1987. The complete report was reproduced in the Geneva Association's Etudes et Dossiers, No. 127 (Oct. 1988).
} 


\section{Introduction}

1. This paper is one of two devoted to the Federal Republic of Germany (hereafter: Germany) within the Geneva Association's Comparative Liability Procedures Project. It seeks in several ways to aid in understanding and evaluating the German system.

2. To this end, the paper provides some basic background information on selected subjects of a legal, factual, and statistical nature. The selection has been made, on the one hand, with a view to the issues that have dominated the American tort reform discussion, especially the conditions and extent of tort litigation and the responsiveness of the insurance market.

Another consideration in selecting the subjects has been the assumed interest of the anticipated readers to know not only about the rules and procedures of an alternative system but also about its cost and effectiveness, as a measure of whether it "works".

It seems necessary to point out here that this information is included only to help the reader understand the German system - not for direct comparison with similar data from other countries, and notably the United States. There are too many and too great differences in the kinds of data collected, in the purposes for which they are collected, the methods of collection and analysis, the definitions used, the reliability of the sources, and other incidents to make such comparison meaningful, apart from the fact that interpretation of the data here and there tends to be influenced by the standpoint of the observer.

As the discussion within the United States shows, there are some basic differences of position, of an almost ideological nature, that make it difficult to agree on objective criteria for deciding whether a given system "works", just as there is no agreement on what "full compensation" means. Given these limitations, it seems nevertheless possible to provide some facts that may serve as a basis for evaluating the effectiveness and efficiency of the German system. In addition to basic information on accidents, losses, and claims, different sources of compensation and their coordination, these include data or estimates on litigation rates and transaction costs.

3. The purposes of the project also require recognition of the dynamic elements of liability and compensation systems studied. Among other things, there has been a tendency among industrialized countries for economic and legal developments to follow similar courses, though with some delay. In the past, developments in Germany have often followed those in the United States, but there are also instances of the reverse.

To show the dynamic aspects of the German system, this paper includes a survey of changes that were made in the recent past, of changes that were recently proposed but rejected, and of current criticisms and proposals for change in the future. The information about changes made or proposed is useful not only as an indicator of gaps or weaknesses in the system but also, by implication, as an indicator of satisfaction and acceptance: every criticism and every proposal of change by necessity includes a statement about those features of the system that are considered satisfactory and therefore in no need for change or even discussion.

4. In addition, this paper takes note of other indicators of satisfaction, acceptance, and potential change, such as existing and changing public attitudes as reflected in opinion surveys. 
5. This paper is based on published information and on information supplied by various trade organizations, whose help is gratefully acknowledged. The responsibility for the statements and conclusions in this paper is exclusively the author's, however.

\section{Compensation Sources}

\subsection{Overview}

As indicated in the Introduction, this paper was written on the assumption that a comprehensive description of tort liability in Germany would be provided by a companion paper. Actually, such comprehensive description has not been written, and the gap cannot now be filled. Some insight into the current state of liability law may be gained from the discussion of trends and proposals in Part VI.

The Federal Republic of Germany is organized as a federal system, consisting of 11 states (Länder) and the national entity or Federation (Bund) formed by them. Unlike the United States Constitution, however, the German Constitution places private law, including tort law, among the matters under federal jurisdiction.

The basic rules of liability are in the civil code (Bürgerliches Gesetzbuch, or BGB) of 1900. Over time, a considerable body of case law has evolved that has expanded and partially modified these rules. In addition, provisions establishing or modifying liability for special situations may be found in special statutes.

It seems fair to say that the substantive rules of tort law in Germany do not differ fundamentally from those of other countries on the European Continent, although there are many differences in detail and in practice. Some of them will become apparent in the discussion which follows.

There are a few points in German law, however, which indeed seem to be unique, or at least worthy of special note:

(a) Strict liability for especially hazardous activities has a long (150 years) tradition in Germany. It was imposed by statute on railroads in the middle of the 19th century, later on gas plants and other installations for generating or transmitting energy, as well as on motor vehicles, aircraft, and installations containing substances capable of polluting the water. Neither the legislature nor the courts have relied on these special statutes to recognize a general rule of strict liability, however.

(b) Damages for pain and suffering are available under German law only where expressly provided by statute, notably the civil code : in cases of personal injury caused by negligence. This restrictive attitude is partially explained by the fact that in prevailing German doctrine damages for pain and suffering do include an element of punishment or retribution for wrongdoing. Consequently, the various strict liability statutes do not provide for compensation of pain and suffering, and as a further consequence, persons who are injured in traffic accidents and who have received full compensation under strict liability and social security schemes for their economic loss still have reason to go to court to claim damages for pain and suffering under negligence rules.

\subsection{Social security}

Germany has the oldest social insurance system in the world, dating back more than 100 years. Over the years, it has evolved into an incredibly complex pattern of benefit and financing rules, and organizational and administrative structures. The German system is 
also one of the most expensive ones in international comparison. Like social security systems elsewhere, the German system has expanded and is still expanding, in terms of persons covered, income limits, situations covered, and benefits.

Over the years, moreover, the established administrative organization and benefit patterns of social security have been used frequently by the legislature to provide what amounts to no-fault compensation for groups of persons and for situations that bear no relation to the original purposes of social insurance.

Especially impressive in this respect is the extension of the range of work accident (workers' compensation) benefits: to several groups of marginal self-employed persons and to types of injuries that, although not suffered in the course of employment in the strict sense, have been found by the legislature to require compensation from public funds because of the public interest inherent in the activity. The following list illustrates not only the dynamic nature of social security but also the wide range of - not always consistent public policy concerns that are involved in its expansion.

Marginal self-employed persons: farmers; operators of commercial vessels in coastal traffic; commercial coastal fishermen; independent subcontractors working at home (cottage industry); artists (actors, musicians, authors, acrobats, etc.); persons providing (except as employees or as independent physicians, dentists, or pharmacists) health services (nurses, midwives, masseuses, physical therapists, chemists, pathologists); veterinarians.

Activities in the public interest: members of voluntary organizations devoted to assistance in accidents and emergencies (Red Cross, road assistance, disaster aid organizations, etc.), including training and practice ; persons participating in civil defense and air raid protection programs; any one injured in an effort to save someone else's life or health in an emergency; persons engaged in providing aid to the poor; donors of blood, organs, or body tissue ; submission to medical examinations required under accident prevention laws; persons appearing at an employment or social agency in compliance with legal requirements; witnesses and lay judges in court proceedings; directors, trustees, and other voluntary administrators of public-law organizations (such as schools, universities, churches, professional and trade boards); students at schools of all kinds and levels, from kindergarten to university; persons serving in the foreign development aid program; persons engaged in constructing or enlarging a single-family dwelling in self-help or under a worksharing arrangement; patients undergoing medical treatment in a hospital or a rehabilitation program in a rehabilitation facility; convicts confined in a correctional institution.

In this context reference must also be made to two types of injury for which compensation from public funds is provided not under the work accident law but under the veterans' benefit law. These are:

- injuries caused by statutorily required or recommended vaccination and

- injuries suffered by victims of violent crimes.

\subsection{Liability insurance}

In addition to motor vehicle liability insurance, which has been obligatory since 1939 , liability insurance coverage is required by statute for the following occupations and activities:

- air transportation operators; 
- hunters;

- public accountants ;

- security services;

- notaries;

- motor transport operators;

- operators of nurses and midwives schools;

- development aid agency;

- nuclear facilities operators ;

- manufacturers of pharmaceuticals;

- real estate brokers and developers.

Control and enforcement of the insurance requirements are strict, penalties for noncompliance are severe, the level of compliance, therefore, is near $100 \%$. Motor vehicle license plates, for instance, will not receive the official stamp until proof of insurance has been provided. If the insurance coverage is terminated for any reason, the insurer must notify the licensing office four weeks before the termination becomes effective; the licensing office, in turn, has the duty to promptly invalidate the license and thus remove the vehicle from circulation. Where due to delay at the office an accident was caused after expiration of the insurance policy, the respective state or municipality has been held liable.

Where liability insurance is not required by law, it is nevertheless common. In business and among professionals it is for practical purposes universal. Roughly one-third of the total premium volume in general liability insurance (DM 3624226000 in 1985) is for commercial and industrial risks. ${ }^{1}$

Among private households, $53.8 \%$ are covered by general liability insurance. ${ }^{2}$

The amounts of coverage are generally much higher than those that are common in the United States. The minimum amounts required by law for private passenger vehicles are:

- DM 1 million (about $\$ 560000$ ) for bodily injury;

- DM 1.5 million if more than one person is injured;

- DM 400000 (about $\$ 224000$ ) for property damage ;

- DM 40000 (about $\$ 22400$ ) for pure economic loss.

In general liability insurance, both commercial and private, the standard amounts of coverage are :

- DM 1 million for bodily injury;

- DM 300000 for property damage.

The amounts apply per occurrence, subject to an annual aggregate limit of twice the amount. Larger amounts are common for commercial and industrial risks.

\section{Coordination and Settlement}

\subsection{Overview of compensation sources}

Social security benefits in Germany are extensive and immediate and provide for the larger part of the economic loss resulting form an accident. Extensive as they are, social

${ }^{1}$ D. Grell, Versicherungswirtschaft 1985, p. 1610.

${ }^{2}$ Source: Statistisches Taschenbuch der Versicherungswirtschaft 1987, Table 16. 
security benefits do not, however, always equal precisely the loss that the injured person could recover under tort law principles. Usually they are less although on occasion they may be more, depending on the type of loss and benefit.

Social security coverage is most complete for medical treatment and care, which are provided in kind and as a rule paid for directly by the carrier. Even here, some minor cost items remain uncompensated, such as private room and similar non-essential comfort.

Disability and survivors' benefits are usually set at a standard percentage of the beneficiary's past and expected future income and are less than could be recovered under tort law. Overcompensation may result, however, where survivors benefits under the work accident insurance system coincide with benefits under the pension system. Coordination rules limit but do not completely eliminate the excess.

No social security benefits are available for pain and suffering and similar non-economic harm, nor for property damage. Claims for these residual losses are routinely made after accidents and are paid by liability insurers.

No comprehensive empirical study comparable to the 1964 Michigan Study, the 1970-71 Department of Transportation Study, or the 1978 AIRAC Study in the United States has been undertaken so far in Germany to show, for a representative sample of accident victims, the extent of their actual economic loss and the extent to which they received compensation therefor from different sources.

The closest equivalent are figures from the internal statistics of the leading German group of insurers, shown in Table 1.

TABLE $1 \quad$ Composition of payments by automobile insurers to injured persons and to subrogation claimants

Type of loss 1970 1975 1980

1. property damage $70.8 \%$ $61.5 \%$ $68.8 \%$

2 . bodily injury subrogation claims from: sickness benefit carriers work accident carriers pension benefit carriers employers

total subrogation claims

injured persons, for:

loss of income or support

medical treatment burial expenses pain \& suffering

Total bodily injury claims

3. Expenses

Totals

\begin{tabular}{rrr}
$4.7 \%$ & $7.6 \%$ & $6.3 \%$ \\
$2.5 \%$ & $4.6 \%$ & $3.5 \%$ \\
$1.6 \%$ & $3.0 \%$ & $2.4 \%$ \\
$1.8 \%$ & $2.3 \%$ & $1.8 \%$ \\
\hline $10.6 \%$ & $17.5 \%$ & $14.0 \%$
\end{tabular}

Source: T. Bäumer, (1982). 
As Table 1 shows, about one-half of the amount paid for bodily injury claims is for losses that were first compensated under social security rules. Of those that are presented by individual claimants, by far the greatest portion (two-thirds) represents non-economic damages. Corresponding figures for other types of liability are not available.

\subsection{Subrogation}

(a) The principle of subrogation

There has long been a strong public policy in Germany against anyone being enriched or gaining an undeserved or unjust benefit from compensation paid under social security or private insurance schemes. Thus, on the one side, total compensation from whatever source may not exceed the injured person's actual loss, and on the other side, compensation and benefits from other sources may not result in the reduction of the liability of anyone who is responsible for the accident under tort law.

Obviously, the collateral source rule of the Common Law systems in the United States and the United Kingdom would be inconsistent with this public policy. Rather, the only way to implement both sides of the policy is to give first-party providers of benefits a right to seek reimbursement from the tortfeasor.

Consequently, the statutes applicable to private insurance contracts as well as those applicable to the various social security programs (including employee, civil service, or veteran's benefit programs and public welfare programs for indigents) all provide specifically that any tort claim that the recipient of benefits may have against a third person shall by statutory assignment pass to the provider of the benefits.

The statutory subrogation rule does not apply to payments received under private life insurance contracts, which are not considered compensation for actually sustained loss. The same exception applies to health insurance policies paying a fixed amount per day of sickness (regardless of actual income loss). Health insurers that do not benefit from statutory assignment frequently provide for contractual assignment of liability claims in their policy forms, however.

The statutory assignment shifts to the benefit provider only that portion of an injured person's liability claim which relates to the same loss for which the benefits were provided, and only in the amount of the benefits.

(b) Conflicts and priorities

To the extent, therefore, that social security or other benefits do not cover the injured person's full loss, the injured remains free to pursue his own liability claim. Thus the injured person and the subrogated benefit provider become competing creditors and, if the amount actually recovered is not sufficient to satisfy both, may end up fighting over the spoils. There are three principal conflict situations due to insufficient recovery:

(i) The tortfeasor's liability for the full amount is not in doubt but his assets are insufficient. For such cases, the applicable statutes clearly provide that the subrogated benefit provider's claim is subordinated to the injured's.

(ii) The tortfeasor's liability is limited by statute (e.g., the law establishing strict liability for motor vehicle owners). Here, too, the injured person's claim is privileged.

(iii) The tortfeasor's liability is reduced on account of the injured person's conduct (comparative negligence). The cases in this last category have been, over the years, the subject 
of considerable controversy and different solutions. In relation to private insurers, the injured person's residual claim has traditionally been privileged but in relation to social security carriers, it was subordinated until 1983. In 1983 the social security rules were consolidated and revised to provide that both the injured person's residual claim and the provider's subrogated claim are to be reduced proportionately.

There are many difficult questions concerning details and special situations, and a considerable volume of case law has accumulated over the years. While the attention given this subject by the courts and in the literature shows that it is a rich potential source of controversy, it also proves that subrogation is generally accepted and practiced.

\section{(c) Summary settlement agreements}

The danger that the benefits of subrogation may be out-weighed by the high cost of implementation has always been recognized, and efforts have been made to keep such costs to a minimum. These efforts have been helped by the fact that the practice of subrogation involves on both sides professional risk carriers, which are designed for routine efficient handling of large numbers of financial transactions.

Consequently, subrogation in German practice takes place, in most cases, through routine notice and bookkeeping transactions on the basis of wholesale settlement agreements between social security carriers and liability insurers (Teilungsabkommen, or loss sharing agreements). Some of these agreements were negotiated and concluded as group or franchise contracts between the respective trade organizations. They have not been joined by all members of the organizations, however. Some carriers and insurers have worked out their own terms, and some prefer to operate without a wholesale agreement. Agreements are most common between liability insurers and social health insurance carriers, somewhat less so with work accident carriers, and infrequent with carriers of old age, survivors, and disability benefits. In all, there are about 1800 individual agreements.

The agreements typically provide that the liability insurer will pay an agreed standard percentage on any claim reported by the social security carrier based on an accident in which one of the liability insurer's insureds was involved. The crucial point is that neither causation nor fault is usually questioned in this procedure if the facts indicate a situation on which liability could be based. This procedure is limited, however, to routine cases not exceeding an agreed amount (DM 10000 to 20000). Exceptionally large or unusual claims are handled individually on the basis of the actual facts.

Some typical percentages payable by liability insurers under summary settlement agreements :

- To work accident carriers: $50 \%$

(covering mostly motor vehicle accidents, including those occurring on the way between an employee's home and place of work, which are covered by social work accident insurance).

- To sickness insurance carriers:

motor vehicle accidents and other accidents under strict liability laws: $\quad 55 \%$

other types of liability: $\quad 45 \%$ 
It has been estimated that in 1984 the total amount of claims settled summarily under loss sharing agreements was DM 700 million, or about one-half of the amount of all subrogation claims collected by social security carriers. ${ }^{3}$

(d) Settlement agreements among auto insurers

Since of all liability claims those made for property damage based on automobile accidents form the largest class and since moreover subrogation in these cases involves automobile insurers on both sides, practically all automobile insurers operating in Germany have entered into standard agreements among one other specifically for such claims. These agreements apply:

- to subrogation claims of insurers that have paid claims for physical damage to a vehicle under the owner's collision coverage; and

- to claims for contribution where, after an accident involving two (or more) vehicles, the insurer of one of the vehicles has paid a liability claim and seeks to collect the share corresponding to the liability of the owners of the other vehicles.

Under the agreements, claims of either type, up to DM 30000 , are summarily split, with each insurer paying $50 \%$ of the total claim. It has been estimated (in 1984) that automobile insurers exchange subrogation payments amounting to about DM 880 million per year. Of this amount, the larger part, about DM 820 million, is settled under the agreements. Only about DM 60 million worth of subrogation claims are settled on the merits.

(e) Economic significance of subrogation

Estimates of the amounts recovered through subrogation by social insurance carriers are shown in Table 2 .

TABLE 2

Receipts from subrogation claims, 1984

Type of carrier

Amount

Work accident insurance carriers

commercial / industrial

DM 320 mill.

agricultural

20 mill.

government / public

50 mill.

Subtotal

390 mill.

Sickness insurance carriers

760 mill.

Old age, survivors, disability carriers

240 mill.

Total for all carriers

DM 1390 mill.

Source: R. Donath, Versicherungsrecht 1984, p. 401

These figures do not include the subrogation receipts of the providers of other social benefits, described earlier, or of private insurers. There are only estimates of the subrogation claims of automobile insurers against one another, at DM 1177 million.

${ }^{3}$ A. Deichl (1985). 
Incomplete as the calculation may be, the resulting total of about DM 2560 million recovered through subrogation is an impressive amount by any standard. As a ratio of total payments by automobile insurers for bodily injury claims, subrogation payments to social insurance carriers are even more impressive, as shown in Table 1.

\section{(f) Summary on subrogation}

Abolition of subrogation has been proposed by some of the advocates of a general nofault accident compensation system, while others want to retain it as a tool of cost internalization; both liability insurers and no-fault promoters have proposed to replace individual subrogation with regular summary contributions to be paid by liability insurers to the various social security carriers. So far, the traditional public policy in favor of subrogation has prevailed. On the occasion of the most recent revision of social security laws in 1983, the subrogation rules were consolidated and amended to make them more favorable for injured persons but without change in the basic principle. Concerns about the cost of collecting subrogation claims are unlikely to have a significant impact given the actual figures and the strength of the underlying public policy, which would not be affected even if the costs were much higher.

A more effective challenge could be based on the argument that the original public policy of subrogation is rendered all but meaningless, especially with respect to automobile accidents, by the existence of complete and universal liability insurance coverage and the widespread use of summary settlement agreements. In defense of subrogation, it can still be argued, however, that the principle of personal responsibility is still recognized even for automobile accidents, that compulsory automobile liability insurance serves primarily the interest of injured persons rather than that of the responsible driver or owner, and that in most other accident situations liability insurance is neither required nor universal.

Apart from the question of individual responsibility and the real or potential deterrent effect of liability on individuals, it is possible to look at subrogation as a means of allocating accident costs among different collectives according to different contributing factors and thus as a means of achieving more effective cost internalization. From this perspective, it does make sense, for instance, to let the burden of automobile accident injuries suffered by employees not be absorbed fully by the employers but to shift at least a portion to the owners of the vehicles involved and thus to make that cost a part of the cost of owning and operating a car.

It seems that considerations of this kind are playing a role in the current discussion. It seems also that in the current discussion, behind the traditional notions of public policy, there are strong institutional interests at play, especially those of the automobile and other liability insurers on one side and those of the social security carriers on the other side. It is as natural for the former to seek to get rid of subrogation as it is for the latter to defend the status quo, especially in a time of rising concern about the cost of social security programs.

Under these circumstances, subrogation can be expected to remain a part of the German accident compensation system as long as that system includes elements of tort liability. A complete change to a no-fault system would eliminate the need for subrogation in the conventional sense although there would still be a need for reimbursements and adjustments among the various carriers or financing sources, similar to the adjustments that are now necessary among social security carriers. 


\section{Litigation}

\subsection{Access to courts}

(a) Overview: conflicting goals

Like the United States, Germany has recently had a period of increased concern about equal protection and access to justice. In that context efforts have been made to make it easier and less costly for all citizens regardless of their means to pursue or defend their rights in court. A significant increase in the volume of litigation ought to have been expected as a sign of success of these efforts; nevertheless, in Germany no less than in the United States, even minor increases have been registered with alarm.

This is but one indication of the conflict between the two equally strong public policies regarding access to the courts - the one that seeks to guarantee to every citizen, however poor, and to every idea, however new, their day in court, and the other one that seeks to promote peaceful reconciliation, to discourage strife, and to prevent abuse of the judicial system.

It is because of this conflict and its political and ideological background that any comparison and evaluation of different rules present enormous difficulties. This should be kept in mind especially in this section where there are particularly pronounced differences between the rules prevailing in Germany and those of the United States. It is also an indication of the inherent antinomy and of the evasiveness of a satisfactory solution that opposite rules are thought, in the respective countries where they prevail, to represent the maximum in fairness and reasonableness. This has become especially apparent in the rules concerning allocation of litigation cost. ${ }^{4}$

(b) Attorney fee payment rules

The fees that German attorneys may, and indeed are expected to, charge for their services are specified by statute - the Bundesgebührenordnung für Rechtsanwälte (BRAGO). Lawyers may not, under the rules of professional conduct, charge less than the statutory fees, except under exceptional circumstances. They may charge more - but only if the client has signed a special and separate agreement to that effect, upon being informed that the agreed fee differs from the one provided in the BRAGO. Such agreements are uncommon for representation in regular matters even with commercial clients.

In contrast to the most common fee standard in the United States, German fees are not based on the amount of time spent by the lawyer. Rather, the BRAGO contains tables of fee units graduated according to the value of the subject matter, similar to tax tables, on a degressive scale. In addition, the BRAGO specifies factors with which the applicable fee units are to be multiplied to arrive at the appropriate fee to be charged. The multipliers reflect the type of service performed rather than the time spent on it. Thus, one unit may be charged for the initial consultation, one for filing an action in court, one for representation in a trial where evidence is taken, one for settling a case in court, etc.

Where the amount in issue is small, this method results in very small fees, which, considering the time spent on the case, are insufficient to cover the attorney's cost and earn him a satisfactory income. This is intended to make legal services affordable to clients of moderate means. Attorneys are expected to have a reasonable mix of clients and

${ }^{4}$ W. Pfennigstorf (1984). 
cases, and the larger fees from large-amount cases are expected to balance the deficit from small cases, on the premise that an attorney will not spend considerably more time on a large-amount case than on one involving only a small amount.

The multipliers are set so as to make settlements an attractive alternative to pursuing a case to judgment. The basic fee units are adjusted from time to time in response to changes in the cost of living.

To the extent that attorneys may negotiate higher than statutory fees with their clients, they may base the agreed fee on other standards, such as the hours worked. They may not, however, under the rules of professional conduct, provide for the fee to be determined as a specified percentage of the amount recovered. The rules of conduct also prohibit agreements that make payment of the fee dependent on the success of the case, unless justified by exceptional circumstances. As such exceptional circumstances so far have not been specified either in the rules of conduct or by the courts, this provision has the practical effect of an outright prohibition of contingent fee arrangements of the kind used in the United States.

(c) Litigation cost allocation

Under the German code of civil procedure (Zivilprozeßordnung, or ZPO) the court must, in its judgment, impose the costs of the matter on the losing party. The costs include court costs (calculated on the basis of statutory standards similar to those for attorney fees) and the necessary expenses incurred by both parties, especially the fees payable to their attorneys in accordance with the BRAGO. The principle thus is the same as the British rule ("costs follow the event"), and the opposite of the "American Rule". 5

A personal injury claim pursued to judgment in the Landgericht after a trial at which evidence is taken will produce the costs shown in Table 3.

TABLE 3

Court and Attorney Fees

\begin{tabular}{|c|c|c|c|c|c|}
\hline Amount claimed (DM) & 2000 & 6000 & 20000 & 100000 & 500000 \\
\hline Court costs & 207 & 450 & 1026 & 2754 & 10314 \\
\hline Plaintiff's counsel & 390 & 993 & 2547 & 5667 & 11607 \\
\hline Defendant's counsel & 390 & 993 & 2547 & 5667 & 11607 \\
\hline Total costs & 987 & 2436 & 6120 & 14088 & 33528 \\
\hline
\end{tabular}

For the average automobile liability claim, which in 1986 was DM 3767, the total costs would be DM 1704 . To these basic costs, there will have to be added a modest amount of sundry expenses for witnesses and experts, etc.).

(d) Legal protection insurance

Both the "American Rule" of cost allocation and the toleration of contingent fees are usually justified as means of giving persons of modest means access to the courts. From a different perspective, they have been cited as a cause of excessive litigation. Conversely, the German rules are given credit for discouraging frivolous and nonmeritorious suits, but they have also been blamed for making access to the courts too costly and too risky for some unconventional but nevertheless "worthy" causes as well.

\footnotetext{
${ }^{5}$ For details, see W. Pfennigstorf (1984).
} 
The effect of the German rules - however it is to be evaluated - is substantially moderated by the availability and widespread use of legal protection insurance. This type of insurance, which is still in its infancy in the United States, has been well established in Germany for many years and is one of the most popular types of personal insurance. In fact, more than $50 \%$ of all German households are estimated to have some kind of legal protection insurance coverage.

Legal protection insurance coverage includes payment of the costs and expenses incurred in pursuing a liability claim against a third party. The insurer pays not only the court costs and the (statutory) fees of the insured's attorney but also, if the court dismisses the insured's claim, the (statutory) fees of the defendant's attorney and other costs imposed by the court on the unsuccessful plaintiff. ${ }^{6}$

As a means to guarantee injured persons access to the courts, legal protection insurance (European style) appears in several respects to be more effective than the American practice of contingent fees. Most importantly, access to the courts does not depend on whether the injured person's claim is large enough to attract the interest of a contingent fee lawyer, and in the event of success the amount awarded by the court to compensate the injured person for his loss is not reduced by the fees and expenses incurred.

Indeed, legal protection insurance has been so successful in Germany that, like the contingent fees in the United States, it has been suspected of encouraging unnecessary litigation. Extensive studies have been conducted to determine whether this suspicion is justified. While there seems to be some abuse with respect to appeals against traffic tickets, the findings with respect to civil and especially tort litigation have been inconclusive. ${ }^{7}$

(e) Legal aid

Persons who lack the means to advance the required fees and costs and who are not covered by legal protection insurance are entitled to legal aid if they meet the statutory standards of need and if their claim is recognized as having a reasonable chance of success and not being frivolous. Given the German rules on cost allocation, the primary objectives of legal aid are to advance the fees and costs required to file an action, and to secure payment of court costs and the fees of the applicant's attorney in the event of defeat. Legal aid fees are lower than the regular statutory fees. If the action is successful, all the costs and fees advanced have to be reimbursed by the losing opponent at the statutory rate. Conversely, if the legal aid recipient loses, legal aid does not cover the opponent's reimbursement claim. This risk is left to be borne by the indigent litigant and his opponent.

\section{(f) Number of attorneys}

On January 1, 1987, 50247 attorneys were admitted to practice before German courts, or one attorney for every 1214 citizens. ${ }^{8}$ The number of attorneys has doubled since 1972 while the population has remained virtually unchanged. This development is

${ }^{6}$ For details on legal protection insurance, see W. Pfennigstorf (1977 and W. Pfennigstorf \& A. M. Schwartz (1986).

${ }^{7}$ See E. Blankenburg (1981-82) and W. Pfennigstorf (1984), at p. 78-82.

8 Bundesrechtsanwaltskammer, in BRAK-Mitteilungen, no. 3/1987, p. 134. 
being watched with great concern by the Bar and by others interested in the judicial system. The rate of increase has dropped, however, during the past three years, from $7.3 \%$ in 1983 to $3.3 \%$ in 1986 . The number of new students embarking on the study of the Law has also levelled off, from 14718 in 1981 to about 9000 in 1986 . Concerns about too many lawyers have been expressed periodically over the past 150 years. They were never strong enough to produce any action to limit access to the profession, although in the early 1930s (during the Great Depression) they did produce stricter rules for suppressing the unauthorized practice of law.

\subsection{Courts and their procedure}

(a) Courts and judges

The courts are organized and operate under federal law. Separate court systems exist for the different areas of law:

- private law and criminal matters;

- labor law matters;

- administrative law matters;

- social security and welfare matters;

- taxation matters.

Each of the systems has its own set of lower (trial) courts, appellate courts, and one federal supreme court. Matters involving the federal constitution (Grundgesetz) are decided by the federal constitutional court (Bundesverfassungsgericht); each state has its own constitutional court.

Liability claims involving small amounts (no more than DM 5000) are tried in the municipal court (Amtsgericht); those involving larger amounts in the circuit court (Landgericht). There are no juries, as explained infra. Decisions of the municipal court may be appealed to the circuit courts (but not further), those of the circuit courts to the court of appeals (Oberlandesgericht). Decisions of the courts of appeal may under certain conditions be appealed to the Supreme Federal Court (Bundesgerichtshof).

There is no equivalent to the American jury in Germany. While lay judges are used to some extent in criminal proceedings and in labor and social security matters, they are entirely foreign to civil procedure. Civil cases are decided at the municipal courts (Amtsgericht) by individual judges and at the circuit courts (Landgericht) by three-judge panels.

Judges are career civil servants. They enter the judiciary immediately following the qualifying examination, without ever having practiced, except for a short period during the practical part of legal education. What judges lack in practical experience in the Bar, they tend to make up over time in experience on the Bench. Although the salaries of judges are not higher than those of civil servants of comparable qualification, rank, and seniority, the prestige of a judicial career is such that traditionally the judicial administrations have been able to select new judges from among the most qualified young lawyers. Appointments are for life subject to retirement according to standard civil service rules. Decisions on appointment or promotion to permanent positions are made, under rules specified in the federal constitution and the respective constitutions of the various Länder, by nomination panels composed of judges, attorneys, government officials, and members of the public appointed by the legislature. 


\section{(b) Moderated adversary procedure}

The absence of a jury reflects a different attitude toward civil procedure - essentially a greater degree of confidence in the integrity of career judges and correspondingly less perceived need to involve laymen in the fact-finding process as a means of democratic control. There are many other differences between German and American civil procedure, both with respect to general principles and with respect to details. They cannot all be described here.

For the purposes of this study, the most relevant difference appears to be that although in principle the German civil procedure is perceived as being an adversary one, it is in practice much less so than American procedure, especially with respect to conducting the trial and to collecting and taking evidence.

Thus, while it is the responsibility of the parties to offer evidence for the facts alleged, the court decides which witnesses to call. If expert testimony is needed, an impartial expert is selected and appointed by the court. Witnesses and experts are examined by the court. Counsel may ask additional questions, including questions concerning a witness' potential bias or an expert' qualification. Aggressive cross-examination, however, is not part of regular trial practice. On the other hand, coaching or rehearsing witnesses is a violation not only of the standards of professional conduct but also of the rules of procedure. ${ }^{9}$

The German rule on cost allocation implies, for the sake of fairness toward the eventual losing party, a duty for the parties and the court to conduct the trial in the most economic manner possible. Among other things, this precludes the calling and examination of witnesses which are not strictly necessary for the court to make a decision on the facts.

Another important difference, loosely related to the considerations just discussed, is that pretrial discovery is unknown in Germany. Parties are expected to come into court with precise allegations of fact and precise offers of evidence to support them. Fishing is not tolerated.

The fact that issues of fact are decided by the court rather than by a jury eliminates the need for most of the restrictive rules that make up the American law of evidence. Although the code of civil procedure contains a list of the principal types of evidence, German judges are essentially free in selecting and assessing the evidence that they consider material for the decision of the case. That decision is subject to appeal, however, and the first appeal (from the Amtsgericht to the Landgericht or from the Landgericht to the Oberlandesgericht, as the case may be, depending on the amount or kind of the case) regularly involves a new trial and a new finding of facts. Only the appeal to the Bundesgerichtshof is limited to questions of law (which, however, may include issues concerning the proper evaluation of evidence).

\subsection{Data on litigation}

\section{(a) Caseload}

No separate statistics are kept on actions in court relating to liability claims for personal injuries or, for that matter, liability claims in general. In the official judicial statistics, liability actions are lumped together with various disputes over contractual rights, property, etc., in a class designated, "other civil matters". Since 1982, however, "traffic accident

\footnotetext{
${ }^{9}$ For details, see J. Langbein (1985).
} 
matters" have been counted as a separate class. The most exhaustive compilation to date of available data on the workload of German courts was undertaken in 1986 by the Federal Department of Justice (Bundesministerium der Justiz) in response to a request of the legislature. Tables 4 and 5 are from this compilation.

Table 4 shows "ordinary proceedings" completed in municipal courts (Amtsgericht). These include contentious, or adversary, proceedings in contract, tort, and property disputes but do not include legal aid petitions, proceedings on claims based on documents or negotiable instruments, injunctions, and matters pertaining to execution, to minors, or to persons placed under a guardian. Table 5 shows the corresponding figures for the circuit courts (Landgerichte). As explained earlier, the respective jurisdictions of the circuit court and the municipal court are defined primarily by the amount at issue, except for some matters (such as landlord/tenant), which are always in the jurisdiction of the municipal court, whatever their amount. As the value of cases increases due to inflation, the municipal courts lose cases to the circuit courts. Adjustment of the threshold amount by the legislature causes a shift in the opposite direction. In the most recent adjustment, the amount was raised from DM 3000 to DM 5000 effective January 1, 1983. These adjustments and other changes in case classification and reporting must be considered in evaluating the tables.

Tables 4 and 5 show that the caseload of both types of courts together has increased by about $21.5 \%$ from 1965 to 1975 and by about $25.1 \%$ from 1975 to 1984 . Concern has been expressed about this increase. It appears modest, however, compared to much larger increases that have occurred in the administrative courts, the social security courts, and the tax courts.

TABLE $4 \quad$ Ordinary proceedings disposed of in municipal courts

Type of

number of cases disposed of in

\begin{tabular}{lccccrrr} 
matter & 1965 & 1975 & 1980 & 1981 & 1982 & 1983 & \multicolumn{1}{c}{1984} \\
\hline Landl/tenant & n/a & 60476 & 78757 & 83586 & 227455 & 233901 & 234676 \\
Support & n/a & 42563 & 4737 & 3558 & 7951 & 6536 & 6829 \\
Traffic acc's & n/a & n/a & n/a & n/a & 100529 & 103749 & 111921 \\
Contractors & n/a & n/a & n/a & n/a & 12720 & 12335 & 12487 \\
Sale / purchase & n/a & 32662 & 24330 & 26948 & 212239 & 204395 & 199087 \\
Other matters & n/a & 702396 & 729531 & 780949 & 412867 & 502611 & 548469 \\
\hline All matters & 791443 & 838097 & 837355 & 895041 & 973761 & 1063527 & 1113469 \\
\hline
\end{tabular}

Source: Geschäftsbelastung der ordentlichen Gerichtsbarkeit; Antwort der Bundesregierung auf die Große Anfrage..., Bundestags-Drucksache 10/1739, Tabellenteil, p. 65

Also, it should be noted that the caseload had declined between 1950 and 1965, that after the most recent increases it has barely returned to the level of 1950 and is still below the level of the first decade of this century, and that there was a much more dramatic increase between 1919 and 1935.10

${ }^{10}$ H. Rottleuthner, Zeitschr. f. Rechtspolitik, 1985 pp. 117-119. 
TABLE 5

Type of

matter

Traffic acc's

Contractors

Sale / Purchase

Other matters

All matters

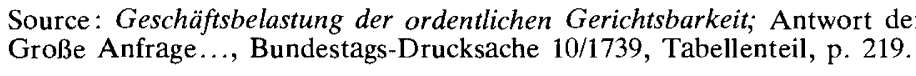

The judges' organization has emphasized the fact that the increase of cases from 1980 to 1984 was not matched by a corresponding addition of new judge positions, resulting in an increase in the caseload per judge from 930 in 1980 to 1038 in $1984 .{ }^{11}$

(b) Litigation rate

In Table 6, the combined traffic accident litigation figures from Tables 4 and 5 are set against the reported accident and insurance claims data for the same years. This is done for the sole purpose of getting a general idea of the dimensions of accident litigation, and with no claim to methodological rigor. For one thing, it is clear that for a methodologically correct analysis, case numbers should not be compared to accident numbers for the same year but for the respective years in which the underlying accident in each of the cases occurred. It must be considered, too, that the cases included in the court statistics are not all liability claims and do not all involve insurers, nor are they limited to automobile accidents. To account for the former fact, the number of claims in the table includes claims not only under the liability coverage but also under comprehensive and collision coverages.

TABLE 6

Automobile accident litigation rates

\begin{tabular}{lccc} 
& 1982 & 1983 & 1984 \\
\hline Number of cases disposed of & 133186 & 129038 & 131678 \\
Number of accidents & 1629000 & 1693000 & 1781000 \\
Cases as \% of accidents & 8.2 & 7.6 & 7.4 \\
Number of insurance claims & 6521000 & 6771000 & 6808000 \\
Cases as \% of claims & 2.0 & 1.9 & 1.9
\end{tabular}

The litigation rate of about $2 \%$ of claims shown in Table 6 is in the vicinity of estimates made in 1973 by Gessner \& Kötz ( $2.3 \%$, based on figures from one major city).

${ }^{11}$ Fuchs-Wissemann, DRiZ 1987 pp. 386-391. 
In contrast, the automobile insurers, citing their own statistics, have put the number of litigated cases (for 1983) at 40000 , and the ratio to claims at $1.2 \% .^{12}$ No corresponding data or estimates ar available for general liability insurance.

(c) Manner of disposition

The compilation of judicial data also contains details about the manner of disposition. This information, however, is not broken down according to the different types of cases or matters. For 1984, the different manners of disposition for all kinds of proceedings were as shown in Table 7.

TABLE 7

Manner of disposition

\begin{tabular}{lrrrr} 
& \multicolumn{2}{c}{ Amtsgericht } & \multicolumn{2}{c}{ Landgericht } \\
\hline Adversarial judgment & 353487 & $(29.2 \%)$ & 101139 & $(30.4 \%)$ \\
Settlement (in Court) & 104880 & $(8.7 \%)$ & 51897 & $(15.6 \%)$ \\
Summary judgm. (default etc.) & 319556 & $(26.4 \%)$ & 65298 & $(19.6 \%)$ \\
Court order & 58898 & $(4.9 \%)$ & 21070 & $(6.3 \%)$ \\
Withdrawal of action or pet. & 199751 & $(16.5 \%)$ & 39653 & $(11.9 \%)$ \\
Other & 172877 & $(14.3 \%)$ & 54183 & $(16.2 \%)$ \\
\cline { 2 - 4 } Totals & 1209499 & $100 \%$ & 333240 & $(100 \%$
\end{tabular}

Terminations by withdrawal indicate out-of-court settlements, which have been found to be especially frequent in traffic accident cases. In contrast, in-court settlements in such cases are rare. ${ }^{13}$

(d) Time needed to settle

Automobile insurers settled $74.8 \%$ of all liability claims filed in 1983 within the same year. Cases involving severe injuries take longer to settle, in part because of the need for more thorough investigation and in part also because the extent of the injuries and losses becomes known only after some time, especially where benefits are first provided by a social security carrier and then claimed by subrogation. ${ }^{14}$ Delays of the latter sort are not seen as a cause of concern since they do not affect the injured person. Generally, private insurers are obligated under the insurance contract law to make partial payments on claims as soon as they can determine that a claim is at least partially justified.

For litigated cases (all kinds), Table 8 shows the percentage of cases disposed of in 1984 within a given time from filing, by municipal courts and circuit courts.

Cases that are appealed several times and then tried again on remand may last 10 years or more.

${ }^{12}$ A. Deichl (1985). This figure represents a substantial increase from the $.4 \%$ ratio that had been reported by Sanden in 1967.

${ }^{13}$ K. F. Röhl (1983).

${ }^{14}$ A. Deichl (1985). 
Time between filing

Percentage of cases disposed of and disposition municipal courts circuit courts

\begin{tabular}{lrr}
\hline 6 months or less & $81 \%$ & $70.1 \%$ \\
$6-12$ months & $14 \%$ & $18.3 \%$ \\
$12-24$ months & $3.7 \%$ & $8.8 \%$ \\
24 months or more & $.5 \%$ & $2.8 \%$ \\
\hline
\end{tabular}

Source: Geschäftsbelastung der ordentlichen Gerichtsbarkeit, Tabellenteil, pp. 69-70, 224.

\section{Costs}

\subsection{Overview}

There are many different reasons and many different ways to look at the costs of accident compensation. In the United States, the recent liability insurance crisis has generated intense interest in the subject and produced a number of studies. ${ }^{15}$ Among the results of these studies, the most significant ones appear to be :

First, they confirm what had been suggested by earlier studies of automobile accident compensation - that the American system of tort liability is very expensive and specifically, that when claims are taken to court, the costs of litigation (broadly defined) tend to equal or even to surpass the net amount received by injured persons. Second, they show a sharp increase of the total amount paid for tort liability claims in the recent past and indeed a growth rate several times the rate of growth of the Gross National Product.

The studies also demonstrate the difficulties and limitations inherent in undertakings of this kind - from defining "cost" to obtaining relevant data to choosing the assumptions and methods for extrapolating from a limited data base. The results are estimates, which, depending on the methods and assumptions chosen, vary considerably.

Studies of comparable dimensions and aims have not been undertaken in Germany although costs have been an issue in the recent public policy discussion. Nevertheless, published figures and estimates do allow some conclusions in regard of the costs of the German system. To provide a broader base for a meaningful evaluation of these figures, this chapter first presents data relating to the dimensions and the cost of accidents, injuries, and their compensation, as well as the incidencc, duration, and cost of litigation.

It seems appropriate at this point to repeat the warning against too direct and too facile comparisons. The data collected in Germany are not necessarily collected for the same purposes, with the same methods, and under the same standards as those collected in the United States. And, of course, they have to be interpreted in the context of an economic, legal, and social environment which, although in many respects similar to that in the United States, is also in many respects quite different.

${ }^{15}$ R. W. Sturgis, The cost of the U.S. tort system, presented to the American Insurance Association at Chicago, November 14, 1985; A. Schotter \& J. Ordover, The cost of the tort system (New York University Department of Economics, March 1986); J. S. Kakalik \& N. M. Pace, Costs and compensation paid in tort litigation (Santa Monica, CA: Institute for Civil Justice, 1986). 


\subsection{Data on accidents}

Accident data are not collected under a uniform coherent system in Germany but rather separately in the different contexts in which they become relevant, with less than complete coordination. Thus, relatively comprehensive and detailed statistics are kept of traffic accidents on the one hand and of work accidents on the other hand. Between the two groups there is obviously a considerable overlap. The third major group is made up of accidents that occur in the house or in the course of leisure activities. This class has long been neglected by the various compensation systems and consequently has received only scant statistical attention even though its aggregate figures are as impressive as those of the other two classes, or even more so. A recent representative study of the Association of German Casualty Insurers has shed some light on the dimensions of these accidents. Tables 9 to 12 show details, separately for each group.

TABLE 9

Road traffic accidents

\begin{tabular}{lcccccc} 
Year & $\begin{array}{c}\text { registered } \\
\text { vehicles } \\
(000)\end{array}$ & $\begin{array}{c}\text { total } \\
\text { accidents } \\
(000)\end{array}$ & $\begin{array}{c}\text { rate } \\
\text { per 1000 } \\
\text { vehicles }\end{array}$ & $\begin{array}{c}\text { accidents } \\
\text { causing } \\
\text { injury }\end{array}$ & $\begin{array}{c}\text { persons } \\
\text { killed }\end{array}$ & $\begin{array}{c}\text { persons } \\
\text { injured }\end{array}$ \\
\hline 1955 & & 603 & & 296071 & 12791 & 371160 \\
1960 & 10217 & 990 & 97 & 349315 & 14406 & 454960 \\
1965 & 13375 & 1099 & 82 & 316361 & 15753 & 433490 \\
1970 & 17837 & 1393 & 78 & 377610 & 19193 & 531795 \\
1975 & 22935 & 1265 & 55 & 337732 & 14870 & 457797 \\
1980 & 29226 & 1684 & 58 & 379235 & 13041 & 500463 \\
1985 & 32091 & 1840 & 57 & 327745 & 8400 & 422095 \\
1986 & 33025 & 1936 & 59 & 341921 & 8948 & 443217 \\
\hline
\end{tabular}

Source: Die deutsche Versicherungswirtschaft, Jahrbuch 1987, pp. 65, 69.

TABLE 10

Work accidents and occupational diseases reported

\begin{tabular}{|c|c|c|c|c|c|c|}
\hline Year & $\begin{array}{l}\text { total } \\
\text { accid. \& } \\
\text { diseas. } \\
(000)\end{array}$ & $\begin{array}{l}\text { accid. } \\
\text { at work } \\
(000)\end{array}$ & $\begin{array}{l}\text { accid. } \\
\text { on the } \\
\text { way } \\
(000)\end{array}$ & $\begin{array}{r}\text { occup. } \\
\text { diseas. } \\
(000)\end{array}$ & $\begin{array}{l}\text { persons } \\
\text { disabled }\end{array}$ & $\begin{array}{c}\text { persons } \\
\text { killed }\end{array}$ \\
\hline 1955 & 2476 & 2180 & 245 & 51 & 1134 & 8233 \\
\hline 1960 & 3028 & 2711 & 283 & 34 & 1094 & 6900 \\
\hline 1965 & 2938 & 2656 & 255 & 27 & 682 & 6865 \\
\hline 1970 & 2673 & 2392 & 255 & 26 & 552 & 6282 \\
\hline 1975 & 1971 & 1761 & 172 & 38 & 513 & 4724 \\
\hline 1980 & 2158 & 1917 & 196 & 45 & 417 & 3998 \\
\hline 1985 & 1752 & 1536 & 179 & 37 & 474 & 2834 \\
\hline
\end{tabular}

Source: Statistisches Taschenbuch 1986, Arbeits- und Sozialstatistik, Table 8.12; Sozialbericht 1986. 
Work accident benefits are paid in about $40 \%$ of the cases reported in Table 10 . The figures in Table 10 include accidents suffered by students in school and on the way to or from school (which, as explained earlier, are compensated since 1971 under the rules and procedures of work accident insurance). Table 11 shows these accidents specifically.

\begin{tabular}{lccccccc} 
TABLE 11 & \multicolumn{9}{c}{ Student accidents } \\
Year & $\begin{array}{c}\text { persons } \\
\text { at risk } \\
(000)\end{array}$ & $\begin{array}{c}\text { accident } \\
\text { rate }\end{array}$ & $\begin{array}{c}\text { total } \\
\text { accid. }\end{array}$ & $\begin{array}{c}\text { at } \\
\text { school } \\
(0000)\end{array}$ & $\begin{array}{c}\text { on way } \\
(000)\end{array}$ & $\begin{array}{c}\text { persons killed } \\
\text { at }\end{array}$ & $\begin{array}{c}\text { on } \\
\text { on }\end{array}$ \\
\hline 1975 & 14595 & 46.9 & 685 & 600 & 85 & 33 & 308 \\
1980 & 14066 & 69.8 & 982 & 875 & 107 & 25 & 184 \\
1984 & 13000 & 77.6 & 1009 & 909 & 100 & & \\
\hline
\end{tabular}

Source: Statistische Mitteilungen 1983, Bundesanstalt für Arbeitsschutz; Sozialbericht 1986.

No regular statistics are kept for accidents occurring at home or during leisure activities. A large-scale representative study undertaken by the Association of German Casualty Insurers (HUK-Verband) produced the estimates shown in Table 12.

TABLE 12

Accidents at home and leisure, 1982, compared to traffic, work, and school accidents

\begin{tabular}{lccc}
$\begin{array}{l}\text { Type of } \\
\text { accident }\end{array}$ & $\begin{array}{c}\text { accidents with } \\
\text { some injuries }\end{array}$ & $\begin{array}{c}\text { accidents with } \\
\text { serious injuries }\end{array}$ & $\begin{array}{c}\text { persons } \\
\text { killed }\end{array}$ \\
\hline traffic & 480000 & 150000 & 11000 \\
work / school & 2500000 & 62000 & 2500 \\
home / leisure & 3000000 & 250000 & 12000 \\
\hline
\end{tabular}

Source: K. Pfund, Bedeutung und Charakteristik von Heim- und Freizeitunfällen, Mitt. der Beratungsstelle f. Schadenverhütung, Nr. 26. (Köln: HUK-Verband, 1985).

\subsection{Data on accident costs and compensation}

As explained earlier, compensation for injuries caused by accident comes from many sources. If it comes from a source that is not specifically designed for accident compensation, it is of no concern whether the injury, disability, or other loss for which benefits are to be provided was caused by an accident, except to the extent that subrogation can be had against a responsible third party. Consequently, reliable data concerning the (firstparty) benefits paid on account of accidents are available only from the carriers of work accident insurance. Their expenses, which include benefits on account of way-to-work accidents, schools accidents, occupational diseases, rehabilitation, and prevention, are shown in Table 13. 
TABLE 13

Expenses of work accident insurance carriers

(DM 000000$)$

\begin{tabular}{lcccc} 
Year & $\begin{array}{c}\text { medical ben., } \\
\text { rehab. etc. }\end{array}$ & $\begin{array}{c}\text { disab. \& survivors } \\
\text { pensions }\end{array}$ & $\begin{array}{c}\text { accident } \\
\text { prevention }\end{array}$ & $\begin{array}{c}\text { total } \\
\text { expenses }\end{array}$ \\
\hline 1960 & 561 & 1191 & 37 & 1789 \\
1965 & 1360 & 1872 & 70 & 3302 \\
1970 & 2199 & 2566 & 116 & 4881 \\
1975 & 3635 & 4335 & 227 & 8197 \\
1980 & 4995 & 6006 & 355 & 11356 \\
1985 & 5766 & 6838 & 497 & 13101 \\
\hline
\end{tabular}

Source: Statistisches Taschenbuch 1986, Arbeits- und Sozialstatistik, Table 8.13.

\subsection{Data on liability insurance claims}

While fairly extensive and detailed statistics are kept on automobile liability claims, the same is not true for general liability insurance. This is due to the differences in the volume and homogeneity of the respective risks. Much of what follows is based on estimates of experienced practitioners rather than on "hard" data. The aggregate claims experience of general liability insurers is shown in Table 14. The figures in Table 14 indicate remarkable stability and easily explain why there is no perception of a "liability insurance crisis" in Germany. No further breakdown of the claims into claims for bodily injury, property damage, or economic loss in the various risk categories is available.

TABLE $14 \quad$ Underwriting results, general liability insurance,

\begin{tabular}{lrccc} 
Year & $\begin{array}{c}\text { net } \\
\text { premiums }\end{array}$ & $\begin{array}{c}\text { Payments } \\
\text { f. claims }\end{array}$ & $\begin{array}{c}\text { claims } \\
\text { ratio }\end{array}$ & $\begin{array}{c}\text { combined } \\
\text { ratio }\end{array}$ \\
\hline 1970 & 858400 & 522741 & $60.9 \%$ & \\
1971 & 998421 & 591666 & $59.3 \%$ & \\
1972 & 1185789 & 720347 & $60.7 \%$ & \\
1973 & 1366329 & 827001 & $60.5 \%$ & \\
1974 & 1517714 & 982358 & $64.7 \%$ & \\
1975 & 1581516 & 1016046 & $62.2 \%$ & $97.0 \%$ \\
1976 & 1720910 & 1127749 & $65.5 \%$ & $98.2 \%$ \\
1977 & 1849727 & 1217014 & $65.8 \%$ & $97.9 \%$ \\
1978 & 2032745 & 1303143 & $64.1 \%$ & $94.9 \%$ \\
1979 & 2210875 & 1450012 & $65.6 \%$ & $96.1 \%$ \\
1980 & 2528022 & 1618994 & $64.0 \%$ & $93.9 \%$ \\
1981 & 2801329 & 1822691 & $65.1 \%$ & $95.2 \%$ \\
1982 & 3003084 & 1993785 & $66.4 \%$ & $96.3 \%$ \\
1983 & 3232761 & 2035487 & $63.0 \%$ & $93.0 \%$ \\
1984 & 3482491 & 2177383 & $62.5 \%$ & $91.8 \%$ \\
1985 & 3624226 & 2457167 & $67.8 \%$ & $96.5 \%$ \\
\hline
\end{tabular}

Source: Bundesaufsichtsamt für das Versicherungswesen, Geschäftsberichte. 
For automobile liability insurance, Table 15 provides basic claims data. Most automobile liability claims are for property damage. Claims for bodily injuries are less frequent but involve larger amounts and are more difficult to settle. Table 16 presents figures that have been stated for 1983 .

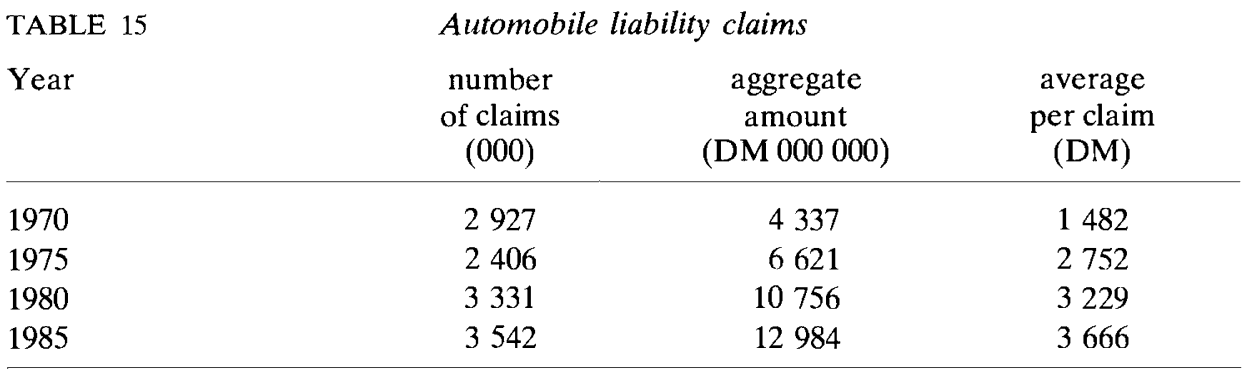

Source: Die deutsche Versicherungswirtschaft, Jahrbuch 1986, p. 57.

TABLE $16 \quad$ Composition of automobile liability claims, 1983

\begin{tabular}{|c|c|c|c|c|c|}
\hline Type of claim & $\begin{array}{l}\text { number } \\
\text { of claims }\end{array}$ & $\begin{array}{l}\% \text { of } \\
\text { total }\end{array}$ & $\begin{array}{c}\text { amount } \\
(000000)\end{array}$ & $\begin{array}{l}\% \text { of } \\
\text { total }\end{array}$ & $\begin{array}{l}\text { average } \\
\text { amount }\end{array}$ \\
\hline \multicolumn{6}{|l|}{ Property damage } \\
\hline repairs & & & 6400 & & \\
\hline economic loss & & & 1200 & & \\
\hline total & 3010000 & 90.3 & 7600 & 63.2 & 2558 \\
\hline \multicolumn{6}{|l|}{ Bodily injury } \\
\hline economic loss & & & 3489 & & \\
\hline pain \& suffer. & & & 1000 & & \\
\hline total & 323000 & 9.7 & 4489 & 36.8 & 13898 \\
\hline Total claims & 3333000 & 100 & 12198 & 100 & 3660 \\
\hline
\end{tabular}

Source: A. Deichl, (1985).

\subsection{Components of tort system costs}

In the absence of special studies of the costs of the tort system, it is only possible to present what scattered incomplete information exists on the various components of those costs: insurers' settlement costs, subrogation costs, litigation costs, and insurers' general administration costs. As indicated earlier, it seems futile to attempt to use these figures as a base for an estimate of total costs that could be compared directly with the American estimates. 
(a) Insurers' settlement costs

Liability insurers do not account separately for costs incurred in claims investigation and settlement. For automobile liability insurance, figures from the internal statistics of the leading group of insurers (Allianz) are shown in Table 17.

\begin{tabular}{lccc} 
TABLE 17 & Composition of Automobile Liability & Claims Costs & \\
Cost item & 1970 & 1975 & 1980 \\
\hline Property damage & $70.8 \%$ & $62.5 \%$ & $68.8 \%$ \\
Personal injury & $22.7 \%$ & $32.9 \%$ & $25.8 \%$ \\
Expenses & & & \\
$\quad$ appraisers \& experts fees & $1.6 \%$ & $1.7 \%$ & $1.9 \%$ \\
$\quad$ excerpts from criminal files & $.4 \%$ & $.3 \%$ & $.3 \%$ \\
$\quad$ court and attorney fees & $4.5 \%$ & $3.6 \%$ & $3.2 \%$ \\
\hline Total & 100 & 100 & 100 \\
\hline
\end{tabular}

Source: T. Bäumer (1982)

For general liability insurance, settlement expenses have been estimated at less than $10 \%$ for claims between DM 10000 and 1 million, and at below $5 \%$ for claims of DM 1 million or more. 16

\section{(b) Litigation costs}

The figures on settlement costs just cited include the costs incurred by the insurer in litigating claims. Since only a very small percentage of claims are litigated, as shown in Table 6, litigation costs appear as a small percentage of total settlement costs. If one looks at litigated claims only, the costs are proportionately larger. The available data do not permit an estimate of the actual costs incurred. As shown in Table 3, the German fee system produces costs that are relatively large for small claims and become smaller as a percentage of larger claims. At the lower end, including the average automobile liability claim, they amount to $45 \%$ of the claim or more for a trial in lower court ending in a judgment. For the cases in this class that are appealed, the costs will exceed the amount of the claim. To estimate the actual costs, one would have to know with reasonable detail the amounts involved in litigated claims and the stage and manner of their final disposition. In evaluating litigation costs, it is also necessary to consider the effects of the German rule on fee shifting.

The insurer's litigation costs shown in Table 17 are primarily costs caused by unsuccessfully contesting a claim, comprising both the fees and expenses paid by the insurer directly and the reimbursable costs, fees, and expenses of the prevailing claimant. If the insurer succeeds in court, its expenses are, within the legal limits, reimbursable by the losing claimant, and they become a cost item for the insurer only if in the exceptional case they cannot be collected. If the claimant in such case is a subrogated social security carrier, these items will in turn show up in the carrier's loss settlement figures. If the losing claimant is an individual, the combined costs may be paid by a legal protection insurer,

16 U. Stürmer (1987). 
as explained earlier. If he is not insured, he bears the burden alone. If he is eligible for legal aid, legal aid will cover the fees of his own attorney and court costs but not the reimbursable expenses of the opponent.

These futile costs of unsuccessful claims have not been measured so far, and are difficult to measure except through detailed empirical study of actual claims. Incidentally, these costs also tend to be ignored in American studies, due to the fact that in most instances, under the prevailing contingent fee agreements, they are absorbed by the plaintiff's attorney (although they indirectly affect the level of fees charged successful claimants).

\section{(c) Subrogation costs}

The cost of collecting subrogation claims is among the arguments cited most frequently in the debate about the merits of subrogation. In the absence of reliable statistical data, the amount of the costs is itself a subject of controversy. The carriers of work acccident insurance have calculated their collection costs at between $6.8 \%$ and $7.5 \% .{ }^{17} \mathrm{~A}$ survey among a sample of health insurance carriers found higher costs: $9.1 \%$ for cases settled under summary settlement or loss sharing agreements, and $17.3 \%$ for cases settled individually on their merits. ${ }^{18}$

There is also disagreement about the corresponding costs incurred by liability insurers. While critics of the system have estimated these costs at about the same rate as those incurred by social security carriers, ${ }^{19}$ it has been pointed out that in the majority of the cases the insurers had to incur unavoidable costs anyway to settle the residual direct claims of the injured persons and that the additional costs of settling subrogation claims were insignificant ${ }^{20}$ For practical purposes, as shown in Table 1 , automobile and other liability insurers include subrogation claims in their general claims accounts and thus the costs of settling subrogation claims, whether individually or under a summary settlement agreement, become part of the aggregate claims settlement costs as shown in Table 17.

\subsection{Total system costs}

To determine the total costs of the liability system, one would have to consider, in addition to the settlement costs, the insurer's general administration and acquisition costs. Indeed, one of the possible methods of measuring the costs of the tort liability system, and certainly the one for which the data base is most reliable and most easily available, is to look simply at the amounts collected and expended by insurers for covering the risk of liability.

In this context, reference must be made to a study prepared by the Economic Studies Department of the Swiss Reinsurance Company, in which liability insurance premiums were analyzed in relation to Gross National Products for several countries over a period of 12 years (1975-1987). ${ }^{21}$ The study shows that in most countries liability premiums have increased at a somewhat greater rate than the GNP but that generally the rate of growth in other countries has been more modest than in the United States.

\footnotetext{
17 Plumeyer (1985).

18 E. von Hippel (1972).

${ }^{19}$ E. von Hippel (1972).

20 Plumeyer (1985).

${ }^{21}$ Liability insurance in the wake of changes in social values - liability rules as a growth factor an attempt at economic analysis (SIGMA No. 6/1988).
} 


\section{Indicators of Dynamic and of Potential Change}

\subsection{Overview}

This chapter looks at the German accident compensation system as part of a living social and political organism and thus subject to continuous pressure for change and indeed continuously changing. These pressures and the nature, direction, and speed of the resulting changes are important matters to know for a meaningful comparison with an even more dynamic American system. The areas of change have ben selected on the basis of their intuitive relevance, with no claim to exhaustiveness and with no attempt at measuring their predictive strength. Any such attempt would be tainted by even more subjective bias than the selection is.

First among the forces operating on the accident compensation system is the universal urge to expand the range of compensation available to injured persons. The fact that, on the one hand, injuries and their more severe consequences cannot be measured in monetary terms and that, on the other hand, many of the accidents result from risks of modern life that are allowed to exist for the sake of general convenience, argues for generosity in compensating the unfortunates who, in a way, are sacrificed for the sake of technical progress whose pleasant sides we all enjoy.

The second major force, related to the first one and equally universal, takes account of the fact that some types of accidents have become a mass phenomenon, and seeks to make compensation as reliable, as equitable, and as rational, and its dispensation as efficient, as those social benefits to which, in our age of entitlements, we have become accustomed.

Third, however, in irresoluble conflict with the egalitarian elements of the entitlement concept, there are the ancient roots of tort liability, often ignored or belittled by modern theorists but persisting or reappearing in impressive shows of continued vitality: individual assignment of moral blame, retribution, deterrence, punishment - taking different forms or disguises but always requiring an evaluation both of the injury and the injuring event on a one-to-one basis.

Fourth among the principal forces is the limitation of the resources, both individual and collective, available for accident compensation. Without negating the principle of individual responsibility, modern society does not like to see an accident bankrupt the responsible individual any more than the injured person. It prefers the burden of compensation to be shifted to, or spread among, larger economic or political units or collectives. As this happens, larger political interests demand a limitation of the total burden.

Evidence of these forces and their interaction will be found in each of the dynamic areas discussed here.

\subsection{No-fault compensation through social security}

The term "no-fault" is used here not in the same sense as it has been used in the United States, where it designates a system in which first-party compensation is linked with a statutory elimination or restriction of liability under tort law. Rather, it is used more loosely to identify a development that, by enlarging the range of compensation from other sources, reduces the demands on the tort system, without a need to impose formal legal restrictions of liability. 
In this sense, the idea if not the name of no-fault has been active in Germany since the mid-1930s, when it was first suggested to "replace liability with insurance". The first areas where the idea was implemented were forwarder's liability and air carrier's liability, which were replaced by private cargo and accident insurance, respectively. Other typical accident situations in which public policy demanded compensation were incorporated into the social security system, as described in Chapter 2.2: accidents suffered by students at school, kindergarten, or college, vaccination damage, injuries caused by violent crimes, etc.

By inclusion in the social security system, compensation according to social security standards is guaranteed. The tort system remains accessible for subrogation by the carrier and for residual claims by the injured person, without, however, being subjected to the stress of having to satisfy immediate elementary needs.

\subsection{Expansion of liability under tort law}

\section{(a) Overview}

Thanks to the wide range of social security coverage, the German tort liability system, unlike the American tort system, has not had to bear the burden of being a primary source of compensation for a large portion of accident victims. Indeed, it has been said that German tort law has thereby been stripped of much of its genuine function and has been reduced to a "law of conditions of subrogation". 22

It is all the more remarkable that the traditional principles of tort law have still been affected by the dynamics of expansion. General recognition of the role of social security as the primary source of compensation in all cases of bodily injury has not been accompanied by a reorientation of tort theory or practice. Compensation of accident victims is still pronounced as the paramount purpose of tort law. ${ }^{23}$ As an equivalent to American "judicial activism", expansion of tort liability has been aggressively pursued by academic writers and by the courts, though at a more moderate pace than in the United States. The arguments for expansion typically ignore the fact that most of the economic loss is covered by social security. 24

Thus, tort liability has been expanded in a variety of ways: by legislation and by case law, in the area of substantive law and in procedure, with respect to the conditions of liability as well as with respect to the burden of proof and the range of compensable damages. Only the most important developments are recounted here.

(b) Strict liability

In Germany, strict liability has been regarded so far as being exclusively in the province of the legislature, rather than the courts. Strict liability laws for railroads, gas works, and certain other dangerous facilities or operations date back almost to the middle of the 19 th century and since then have been expanded from time to time in response to technological developments. Later, strict liability was introduced for motor vehicles, aircraft, and funicular railways, and for facilities and activities that cause water pollution.

In 1971, following a series of severe congenital defects caused by the drug thalidomide, a system of strict liability supported by obligatory insurance was established for manufac-

\footnotetext{
22 H. -L. Weyers (1971).

${ }^{23}$ E. von Hippel (1980).

${ }^{24}$ For details, see B. S. Markesinis (1986a) \& (1986b).
} 
turers of pharmaceutical drugs. Effective January 1, 1990, the Federal Republic of Germany established strict liability for defective products, following the mandate of the European Communities aimed at harmonizing product liability law in the Community. There are proposals to expand strict liability to ski lift operators and to all facilities which may cause pollution of the environment.

Over the past several years, there has been a discussion whether to replace the traditional legislative piecemeal approach with a general rule of strict liability for "especially dangerous" facilities of activities. So far, no agreement could be reached on the proper definition and limitation of the situations to be subjected to strict liability, however ${ }^{25}$

\section{(c) Strict duties of care with reversed burden of proof}

While the courts so far have refrained from going beyond the legislature in recognizing strict liability, they have in many respects achieved the same result by recognizing very strict standards of care and imposing on the defendant the burden of proving that the standard was indeed met. In this fashion, the courts have fashioned entire new areas of tort liability that did not formerly exist. Product liability is the most prominent example. Other areas of vigorous expansion are the various forms of professional liability, especially that of physicians, architects, and engineers, as well as liability of the owners of premises and the operators of sports facilities. ${ }^{26}$

In sports, there has been a tendency to ignore the traditional acceptance of risk doctrine in favor of increased demands of care on organizers and fellow sportsmen. This has been most pronounced in skiing, for which complete new codes of conduct have emerged, but it can also be observed in mountain climbing and even in team sports such as soccer.

\section{(d) Expansion of compensable damages}

Like American courts, German courts have been under continuous pressure for recognition of a wider range of compensable damages. The most remarkable advances have been in the area of hypothetical economic loss.

Thus, if an accident has caused physical damage to a vehicle, the courts now routinely award, in addition to the costs of repair and the costs of procuring alternative transportation, an amount reflecting the reduced resale value of the damaged vehicle, irrespective of whether the owner actually sells it or intends to sell it. Similarly, German courts have recognized, subject to certain qualifications, loss of use of the damaged vehicle pending repair as an abstract item of loss that may be recovered even if the owner did not in fact rent a substitute vehicle. The courts have so far refused to apply the same principle to loss of use of real property or to other kinds of personal property. The privileged treatment of automobile claimants has been explained by the large number of claims and the need to expedite settlement through pragmatic use of standardized compensation.

The abstract value of a person's time has been recognized in cases involving death or disability of a housewife and mother. In such cases, the courts now allow recovery measured on the basis of the cost of substitute services even if the family manages to get along without actually hiring help. Finally, the value of recreation time has been recognized

\footnotetext{
25 For details, see H. Kötz (1981).

${ }^{26}$ For details, see C. von Bar (1980).
} 
as a compensable item of loss, reflecting the expansion of commercialized tourism. Thus, the civil code now provides that where a travel agency or tourism organization has breached its contractual duties (e.g., by losing the customer's luggage or providing inadequate facilities), the customer can claim compensation for the economic value of the spoiled vacation.

With respect to nonpecuniary damages, German law continues its traditional restraint. The civil code allows payments for pain and suffering only in cases of bodily injury and unlawful imprisonment. The courts have awarded similar payments in severe cases of invasion of privacy. The various statutes establishing strict liability have so far provided compensation only for actual economic loss. Thus an injured person can recover for pain and suffering only if he can establish liability on the traditional tort-law basis of negligence. Recently there have been demands to eliminate this limitation.

There being no juries in German civil procedure, awards for pain and suffering are made by the court on the same basis as for other damages. The awards must be supported by reasons and are subject to review on appeal along with the rest of the decision. As a consequence, courts are careful to stay within the customary pattern of awards for comparable cases. There are extensive tables in which all known awards are compiled and organized for easy comparison. The general level of awards is modest by American standards. The amounts tend to increase in response to increases in the cost of living and generally rising expectations. The increases take place in small increments, however.

Punitive or exemplary damages are not now recognized in German law and are not likely to be recognized in the future. It is recognized, however, that the concept of nonpecuniary damages is in part based on the idea of retribution and that consequently elements of retribution or punishment may be reflected in the amount awarded for pain and suffering.

\subsection{Changes in procedures}

In recent amendments of the rules of civil procedure, the principal aims have included easier access to the courts (through an expansion of the legal aid system), reduction of the time needed for disposition (by requiring parties to concentrate their allegations of fact and by providing for more condensed trials), and encouragement of settlements. Although the time has been too short for a thorough evaluation, tentative studies suggest that the time-saving measures have had some effect. ${ }^{27}$

Investigation and mediation panels for medical malpractice claims have been created by many regional medical boards. On an entirely voluntary basis, they seek to reduce litigation by offering an impartial expert forum for reviewing and settling medical injuries. Participation is voluntary, the recommended settlements are not binding, and there are no restrictions on subsequent court action. The panels have not been in operation long enough to allow a reliable evaluation.

\subsection{Expansion of liability insurance coverage}

Liability insurance has long been recognized as an important part of the accident compensation system. This is demonstrated by the long list of activities for which liability insurance is required by law. The public policy role of liability insurance, and especially

\footnotetext{
${ }^{27}$ Rottleuthner (1987).
} 
obligatory liability insurance, is further reflected in statutory modifications of the insurance contract designed to protect third-party claimants. Among other things, automobile liability insurers are subject to direct action by the injured person, in which they may not rely on most of the defenses that they may have against the insured under the terms of the policy. 28

The coverage has also been expanded by extending to the injured policyholder and other insured persons the rights of a third party - disregarding some of the basic principles of liability insurance. Thus, among other things, the standard family exclusion was removed, and claims (for bodily injury only) by the policyholder or owner against other insured persons were included. Moreover, after the insurers had most of their contractual defenses taken away in relation to third-party claimants, a tendency developed in the courts to restrict insurers also in enforcing their recourse claims against the offending policyholders (i.e., those who violate the contract by failing to report accidents promptly, to cooperate with the insurer, and to minimize the loss). Eventually, responding to the increasing pressure, the insurers amended their policy terms to limit recourse in such cases to DM 1000 for negligent and even most intentional breaches and to DM 5000 for particularly severe intentional breaches.

\subsection{Compensation funds}

A motor vehicle accident compensation fund was established in compliance with the terms of a European Convention. ${ }^{29}$ It provides compensation is cases where the strict liability / obligatory insurance system fails:

- Hit-and-run accidents (where the responsible vehicle and its owner and insurer cannot be identifed);

- accidents caused by uninsured vehicles;

- accidents caused deliberately (and therefore not covered, as a matter of public policy, by liability insurance).

The third type of accidents was only added in 1976, as part of the legislation providing relief to the victims of violent crimes.

A separate fund was created voluntarily by the insurers in 1968 to guarantee compensation in the event of insolvency of the vehicle's insurer. Its purpose is limited to automobile liability insurance claims.

The Thalidomide (Contergan) cases of the 1960s, involving hundreds of children born without limbs and with other congenital defects, resulted in a settlement under which a foundation was established, funded with contributions from the pharmaceutical industry and the government, to dispense rehabilitation and support benefits over the lifetime of the victims. ${ }^{30}$

\subsection{Criticism and reform proposals}

As may be expected, the existing, historically evolved pattern of accident compensation has been the subject of criticism. It is easy to agree with critical observers that the

\footnotetext{
${ }^{28}$ For details, see W. Pfennigstorf (1967).

${ }^{29}$ For details, see W. Pfennigstorf (1967).

${ }^{30}$ For details see $J$. G. Fleming (1982).
} 
system is complex, lacks solid theoretical foundations, suffers from some inconsistencies and some inequities, and operates less efficiently than would be desirable. It is also easy to agree that the present system does not guarantee full compensation at tort law standards (i.e., indcluding $100 \%$ of lost earnings, and nonpecuniary damages) for everyone who is injured by an accident.

Agreement ends when the discussion turns to the evaluation of the specific instances of less than full compensation: whether they represent cases that sound public policy ought to leave outside the system, whether they are merely undesirable blemishes that for the sake of overall balance can be ignored, or whether they are unacceptable faults calling for major remedial action.

Much less is there agreement on the specific changes that ought to be made. Both in the identification and evaluation of gaps and in the proposed remedies, basic differences in political views become evident - the conflicting views and forces referred to in the beginning of this chapter.

The aspects most frequently singled out for criticism and reform proposals are:

- accidents suffered at home and during leisure activities, for which no third person can be blamed;

- traffic accidents excluded from the strict liability regime, notably those caused by unavoidable occurrences (e.g., wild animals or an act of God);

- incomplete compensation under strict liability due to:

- reduction on account of the victim's own negligence or of the inherent risk of his own vehicle ;

- statutory limits;

- exclusion of recovery for nonpecuniary loss (pain and suffering);

- limitations of obligatory liability insurance coverage :

- lack of insurance coverage for accidents caused by bicyclists or pedestrians;

- lack of coverage for intentionally caused injury or damage.

Some of the most urgent demands (e.g., coverage for claims by relatives and by the policyholder against other insureds) have recently been satisfied through amendments of the policy terms.

While most complaints concern perceived gaps in the compensation system, instances of overcompensation and of cumulation of social security benefits have also been criticized, as has the insurers' failure to exclude coverage (i.e., reserve for themselves a right of recourse against the insured) in cases of drunk driving. The long-standing coverage under work accident insurance of accidents suffered by employees on their way to or from work has also been criticized as a misallocation of part of the costs of automobile traffic.

Proposals range from modest adjustments to radical reform. Among the most radical proposals, one would replace the present system with a universal accident compensation program patterned largely after the New Zealand model. Its proponents claim that it would eliminate most of the gaps and inequities of the present system, would be more economical to operate, and would permit more precise cost allocation for the maximum 
possible internalization and deterrence. ${ }^{31}$ This extreme proposal has not found much support, however, principally because hardly anyone else has been persuaded that the system is in need of drastic reform.

Rather, the prevailing view seems to be that the overall performance of the existing systems is satisfactory and does not warrant the expense and the risk of a radical change to a different system that only offers a promise to be simpler. Minor changes within the system are all that is needed, according to this view, to close gaps and expand benefits where there should be a sufficiently strong public demand therefor.

To a considerable extent, the case for total reform has been based on the argument of cost, that is, the argument that the administration, litigation, and other "transaction" costs of the present system are too large compared to the costs of present social security programs and the expected costs of a potential universal accident compensation program. In challenging this argument, reference has been made to the hidden costs of present social security programs (especially costs absorbed by employers) and to the uncertainties in predicting the costs of a potential universal accident compensation program in view of high and rising public expectations with respect to individualized settlement of accident compensation claims.

As might be expected, both social insurance carriers and private insurers are opposed to radical change that would diminish their role in settling accidental injuries. For that very reason, however, private insurers, especially automobile insurers, have been eager in the past two decades to accommodate demands for extensions of coverage.

At the same time, there is growing concern about the cost of social security, which by general agreement has reached the limits of what private households and the national economy will tolerate. The national legislature, like legislatures in other countries, has been considering measures to contain costs, especially in health insurance. Consequently, the changes that are in progress or under serious discussion at present are small-scale specific changes within the existing system rather than wholesale reform.

Specifically:

- extension of strict liability to operators of ski lifts;

- expansion of strict liability of operators of facilities involving hazardous substances beyond water pollution to pollution of the air and the ground:

- obligatory liability insurance for activities involving hazardous substances;

- expansion of strict liability of motor vehicle keepers and/or coverage under obligatory motor vehicle liability insurance by

- eliminating or restricting defenses ("unavoidable occurrences", contributing negligence);

- eliminating the statutory limits on liability;

- providing for payment of nonpecuniary damages.

Finally, there is growing recognition that certain damage situations cannot be handled satisfactorily in the existing system since they defy the traditional concept of individual allocation of fault and responsibility. These include injuries, property damage, and environmental harm due to hazardous materials or conditions, involving long periods of time and multiple and uncertain causation.

31 E. von Hippel (1980). 
Special concern has been caused by the cases of damage to forests, for which a combination of acid rain, automobile exhausts, and various other environmental and biological factors has been blamed. For these, the establishment of special compensation funds is seen as the only satisfactory solution, with the cost to be spread by means of individual or collective contributions calculated on the basis of available information about potential contributions to causation.

\subsection{Public opinions, attitudes, and other indicators of acceptance or impending change}

The overall impression of the German accident compensation system usually projected by insiders and by outside observers as well is one of comprehensiveness, moderation, and stability. The generally positive picture is not exclusively the result of substantive rules but also the result of a combination of other less tangible factors, including procedural rules and court practices discouraging extreme forms of adversary tactics, a tradition among insurers to avoid litigation, and a preference for continuity, stability, and discipline in a strictly supervised insurance market.

Some of these other factors are subject to change and may indeed be affected by change already. Thus, the efforts to increase competition in a common European insurance market imply a reduction of regulatory restraints. Even though it is unlikely that price competition will ever be as intense as it has been in the United States, it is possible that a change in the competitive climate may have an effect also on insurers' and insureds' attitudes with respect to long-term relationships and the settling of claims.

Public attitudes about making claims are also changing. Insurers have become increasingly concerned about the "moral risk", and especially about padded and fraudulent claims. Public opinion researchers have found a higher level of tolerance toward dishonesty in insurance and similar matters. ${ }^{32}$ This finding is confirmed by what appears to be an alarming deterioration of manners among motorists. As the courts and the insurers have softened the consequences of breaches of contract conditions, hit-and-run accidents have been increasing at a dramatic rate..$^{33}$

At the same time, a widespread willingness among motorists to avoid payment of fines for parking violations by denying that they personally used the car on the given occasion has forced the legislature to make changes in the fee system designed to make this ploy financially unattractive. What is alarming in this context is not so much that the ploy was used but that, as one expert estimated, it was used in about 3 million cases (out of a total of 15 million parking citations) in one year. ${ }^{34}$

Casual observation of daily life and political discussion confirms the impression that this is a time of great tolerance toward "alternative", irresponsible and even lawless behavior. At a rather late stage of the antiauthoritarian movement, in a time that has also been referred to as that of the "Me-Generation", it is difficult to predict how long the development will continue in the same direction and when responsibility and respect for the rights of others will be rediscovered. History has known similar shifts in attitudes and suggests that present conditions need not be indicators of irreversible change.

32 E. Noelle-Neumann, Zeitsch. ges. Versicherungswiss. 1985, pp. 583-610.

${ }^{33}$ E. Höfle, Anwaltsbl. 1987, pp. 429-436.

${ }^{34}$ R. Mößinger, D. Autorecht 1985, pp. 267-273. 


\section{REFERENCES}

BAR, Ch. von (1981a), Deliktsrecht: Empfiehlt es sich, die Voraussetzungen der Haftung für unerlaubte Handlungen mit Rücksicht auf die gewandelte Rechtswirklichkeit und die Entwicklungen in Rechtsprechung und Lehre neu zu ordnen? Wäre es insbesondere zweckmäßig, die Grundtatbestände der Par. 823 Absätze 1 und 2, Par. 826 BGB zu erweitern oder zu ergänzen? in Gutachten und Vorschläge zur Überarbeitung des Schuldrechts, hrsg. Bundesminister der Justiz, Bd. II, pp. 1681-1778. Köln, Bundesanzeiger.

BAR, Ch. von (1981 b), Das "Trennungsprinzip" und die Geschichte des Wandels der Haftpflichtversicherung, in: Archiv f. d. civilistische Praxis, Vol. 81, pp. 289-327 (1981).

BAR, Ch. von (1980), Verkehrspflichten: Richterliche Gefahrsteuerungsgebote im deutschen Deliktsrecht, Köln: Heymann, 1980.

BAUMANN, H. (1975), Soziale Sicherung gegen Unfälle im Straßenverkehr? in: Viertelj. Schr. f. Sozialrecht, 1975, pp. 1-45.

BÄUMER, T. (1982), Hat das deutsche Kraftfahrzeug-Haftpflichtversicherungs-System eine Zukunft? (Beiträge zum Privat- und Wirschaftsrecht, No. 42). Karlsruhe: Verlag Versicherungswirtschaft, 1982.

BLANKENBURG, E. (1981-82), Legal Insurance, Litigant Decisions, and the Rising Caseload of Courts: A West German Study, in: 16 Law \& Society Rev. 601, (1981-82).

BLANKENBURG, E. (1986), Mehr Justiz, aber weniger Gerechtigkeit? in: ZRP 1986, pp. 262-267.

BLANKENBURG E. (1987), Weniger Prozesse durch mehr Rechtsberatung, in: DRiZ 1987, pp. $169-178$.

BLANKENBURG, E. and FIEDLER, J. (1981), Die Rechtsschutzversicherungen und der steigende Geschäftsanfall der Gerichte (Reform der Justizreform, Band 8). Tübingen: J.C.B. Mohr (Paul Siebeck), 1981.

BODEWIG, Th. (1985), Probleme alternativer Kausalität bei Massenschäden, in: Archiv f. d. civilistische Praxis, Vol. 185, pp. 505-558 (1985).

BRÜGGEMEIER, G. (1986), Judizielle Schutzpolitik de lege lata - Zur Restrukturierung des BGBDeliktsrechts, in: JZ, 1986, pp. 969-979.

BRÜGGEMEIER, G. (1983), Perspectives on the Law of "Contorts". A Discussion of the Dominant Trends in West German Tort Law, in: 6 Hastings Int'l \& Comp. L. Rev. 355-398 (1983).

DEICHL, A. (1985), Die Schadenregulierung der Kfz-Haftpflichtversicherer, in: VersR 1985, pp. 408-412.

DENCK, J. (1982), Verdrängung des Haftungsrechts durch Teilungsabkommen? in: NJW, 1982, pp. 2048-2056.

DEUTSCH, E. (1971), Die Zwecke des Haftungsrechts, in: JZ, 1971, pp. 244-248.

DIEDERICHSEN, U. (1987), Altlasten und WHG-Deckung, in: Versicherungspraxis, 1987, pp. 85-93.

DIEDERICHSEN U. (1986), Die Verantwortlichkeit für Altlasten im Zivilrecht, in: Betriebsberater 1986, pp. 1723-1731.

DINSLAGE, K. H. (1981), Patientenversicherung - Alternative zur Arzthaftpflicht, in; VersR 1981, pp. $310-313$.

DONATH, R. (1984), Offene Fragen zum Regreß nach dem Sozialgesetzbuch, in: VersR 1984, pp. 401-406.

FLEMING, J. G. (1982), Drug Injury Compensation Plans, in: 30 Am J. Comp. L. 297-323 (1982). 
FLEMING, J. G., HELLNER, J. and HIPPEL, E. von (1980), Haftungsersetzung durch Versicherungsschutz: Länderberichte zum anglo-amerikanischen Recht und zum schwedischen Recht zusammen mit einem rechtsvergleichenden Generalbericht und einem Bericht über die Diskussion. Verhandlungen der Fachgruppe für Zivilrechtsvergleichung auf der Tagung für Rechtsvergleichung in Lausanne, 12. - 15. September 1979 (Arbeiten zur Rechtsvergleichung Bd. 100). Frankfurt a. M.: Alfred Metzner, 1980.

FUCHS-WISSEMANN, G. (1987), Zur Geschäftsbelastung der ordentlichen Gerichtsbarkeit, in: DRiZ, 1987, pp. 386-391.

GEIGEL, (1986), Der Haftpflichtprozeß mit Einschluß des materiellen Haftpflichtrechts, 9. Aufl., hrsg. von Günter Schlegelmilch. München: C.H. Beck, 1986.

GESSNER, V. and KÖTZ, H. (1973), Verkehrsunfälle vor Gericht: Eine rechtstatsächliche Untersuchung, in: JZ 1973, pp. 82-87.

GRELL, D. (1985), Haftpflichtversicherer vor großen Herausforderungen und Sorgen, in: Versicherungswirtschaft 1985 , pp. 1610-1618.

GRELL, D. (1987a) Die Haftpflichtversicherung im Wandel der Zeit, in: Versicherungswirtschaft, 1987, pp. 122-130.

GRELL, D. (1987b) Neue Schwerpunkte in der Haftpflichtversicherung, in: Versicherungswirtschaft 1987, pp. $1509-1517$.

Grenzen der Rechtsgewährung: Die Vorträge und Referate des Deutschen Richtertages 1983 in München, hrsg. vom Deutschen Richterbund. Köln: Heymann, 1983.

HACKS, S., RING, A. and BÖHM, P. (1987), Schmerzensgeld: Beträge, Ausg. 1987. München: ADAC-Verlag, 1987.

HAGER, G. (1986), Umweltschäden - ein Prüfstein für die Wandlungs- und Leistungsfähigkeit des Deliktsrechts, in: NJW 1986, pp. 1961-1971.

HEIDEL, U. and WULFERT W. (1978), Konsequenzen aus der Neufassung des Par. 11 AKB, in: VersR 1978, pp. 194-197.

HOFMANN, E. (1976), Die Änderungen des Par. 7 AKB und der Geschäftsplanmäßigen Erklärung für die Kraftfahrzeugversicherung, in: VersR 1976, pp. 308-314.

HOHLOCH, G. (1981), Allgemeines Schadensrecht: Empfiehlt sich eine Neufassung der gesetzlichen Regelung des Schadensrechts (Par. 249-255 BGB)? in: Gutachten und Vorschläge zur Überarbeitung des Schuldrechts, hrsg. Bundesminister der Justiz, Bd. I, pp. 375-478. Köln: Bundesanzeiger (1981).

HÜBNER, H. (1986), Noch einmal: Gefährdungshaftung und Verantwortung, in: Festschrift für Wolfram Müller-Freienfels. (Baden-Baden: Nomos, 1986), pp. 329-339.

HÜBNER, U. (1972), Die Haftung des Gardien im französischen Zivilrecht. Karlsruhe: C. F. Müller, 1972.

HÜBNER, U. (1982), Zur Reform von Deliktsrecht und Gefährdungshaftung, in: NJW 1982, pp. 2041-2048.

International Encyclopedia of Comparative Law. Vol. XI: Torts (André Tunc, Chief Editor). Tübingen \& The Hague: J. C. B. Mohr (Paul Siebeck) \& Martinus Nijhoff, 1984.

Vol. XVI: Civil Procedure (Mauro Cappelletti, Chief Editor), Ch. 6: Ordinary Proceedings in First Instance. Tübingen \& The Hague: J. C. B. Mohr (Paul Siebeck) \& Martinus Nijhoff, 1984.

JAHR, G. (1983), Schadenersatz wegen deliktischer Nutzungsentziehung - zu Grundlagen des Rechtsgüterschutzes und des Schadenersatzrechts, in: AcP, Vol. 183, pp. 725-794 (1983). 
JOKL, St. (1976), Die Belastung der Volkswirtschaft durch Unfälle. Schriftenreihe zur Industrie- und Entwicklungspolitik, hrsg. von Fritz Voigt, Bd. 21. Berlin: Duncker \& Humblot, 1976.

JOKL, St. (1983), Die volkswirtschaftlichen Kosten der Arbeitsunfälle. Forschungsbericht Nr. 328 der Bundesanstalt für Arbeitsschutz und Unfallforschung. Dortmund: Wirtschaftsverlag NW, 1983.

KARPEN, U. (1987), Für eine Tumultschadenshaftung des Staates, in: ZRP 1987, pp. 349-351.

KEGEL, G. (1983), Haftung für Zufügung seelischer Schmerzen. Opladen: Westdeutscher Verlag, 1983.

KIMBAL, S. L. and PFENNIGSTORF, W. (1981), The Regulation of Insurance Companies in the United States and the European Communities: A comparative Study. Washington, D. C.: International Insurance Advisory Council, Chamber of Commerce of the United States, 1981.

KLINGMÜLlER, E. (1980), Zu den Plänen einer neuartigen Patientenversicherung nach schwedischem Muster in der Bundesrepublik Deutschland, in: VersR 1980, pp. 694-696.

KÖTZ, H. (1983), Deliktsrecht. Eine Einführung. 3. Aufl. Frankfurt a. M.: Alfred Metzner, 1983.

KÖTZ, H. (1981), Gefährdungshaftung: Empfiehlt sich eine Vereinheitlichung und Zusammenfassung der gesetzlichen Vorschriften über die Gefährdungshaftung im BGB und erscheint es erforderlich, das Recht der Gefährdungshaftung weiterzuentwickeln? in: Gutachten und Vorschläge zur Überarbeitung des Schuldrechts, hrsg. Bundesminister der Justiz, Bd. II, pp. 1779-1834. Köln: Bundesanzeiger, 1981.

KÖTZ, H. (1970), Haftung für besondere Gefahr: Generalklausel für die Gefährdungshaftung. in: Archiv f. d. civilistische Praxis, Vol. 170, pp. 1- (1970).

KÖTZ, H. (1982), Sozialer Wandel im Unfallrecht (Schriftenreihe d. Juristischen Studiengesellschaft Karlsruhe, Heft 125). Karlsruhe: C. F. Müller, 1976.

LANGBEIN, J. H. (1985), The German Advantage in Civil Procedure, in: 52 U. Chicago L. Rev. 823-866 (1985).

LAWSON, F. H. and MARKESINIS, B. S. (1982), Tortious Liability for Unintentional Harm in the Common Law and the Civil Law, Volumes I and II. Cambridge: Cambridge University Press, 1982.

LORENZ, E. (1981), Immaterieller Schaden und "billige Entschädigung in Geld": Eine Untersuchung auf der Grundlage des Par. 847 BGB. München \& Berlin: Duncker \& Humblot, 1981.

LUDWIG (1986), Die Unzulänglichkeit des Schadenersatzes beim Ausfall einer Hausfrau und Mutter, in: DAR 1986, pp. 375-383.

LUTZEIER, G. (1987), Unfallversicherung - Immense Kosten, in: Bundesarbeitsblatt 1987, Nr. 7-8, pp. 22-23.

MARBURGER, P. (1986a), Ausbau des Individualschutzes gegen Umweltbelastungen als Aufgabe des bürgerlichen und öffentlichen Rechts (Gutachten C zum 56. Deutschen Juristentag). München: C. H. Beck, 1986.

MARBURGER, P. (1986b), Wissenschaftlich-technischer Sachverstand und richterliche Entscheidung im Zivilprozess (Schriftenreihe d. Jur. Studienges. Karlsruhe, Nr. 174). Heidelberg: C. F. Müller, 1986.

MARKESINIS, B. S. (1986a) A Comparative Introduction to the German Law of Torts. Oxford: Clarendon Press, 1986.

MARKESINIS, B. S. (1986b), Conceptualism, Pragmatism and Courage: A Common Lawyer looks at some Judgments of the German Federal Court, in: 34 Am. J. Comp. L. 349-366 (1986).

MARKESINIS, B. S. and BAR, Ch. von (1981), Richterliche Rechtspolitik im Haftungsrecht (Recht und Staat, 502/503). Tübingen: J. C. B. Mohr (Paul Siebeck), 1981. 
BIEBERSTEIN, W. Freiherr M. von, (1983), Zur Neuregelung des Haftpflichtregresses der Sozialversicherungsträger in Par. 116 SGB X, in: ZVersWiss 1983, pp. 99-119.

MEDICUS, D. (1986), Zivilrecht und Umweltschutz, in: JZ 1986, pp. 778-785.

OSTERMANN, H.-J. (1987), Unfallverhütungsbericht 1985 -- Weniger Tote, in: Bundesarbeitsblatt 1987, Nr. 2, pp. 17-20.

PFENNIGSTORF, W. (1970), Analysis of the German Auto Accident Compensation System, in: Comparative Studies in Automobile Accident Compensation (Department of Transportation Automobile Insurance and Compensation Study), pp. 33-63. Washington, D. C.: U. S. Government Printing Office, 1970.

PFENNIGSTORF, W. (1977), The European Experience in Legal Expense Insurance, in: Werner Pfennigstorf \& Spencer L. Kimball, eds., Legal Service Plans: Approaches to Regulation, pp. 487-565. Chicago: American Bar Foundation, 1977.

PFENNIGSTORF, W. (1984) The European Experience with Attorney Fee Shifting, in: 47 Law \& Contemp. Problems 37-124 (1984).

PFENNIGSTORF, W. (1986) German Insurance Laws (Translated and annotated), 2d ed., Karlsruhe, Germany: Verlag Versicherungswirtschaft e. V., 1986.

PFENNIGSTORF, W. (1967), Unification of the Protection of Traffic Victims in Europe, in: 15 Am. J. Comp. L. 436-456 (1967).

PFENNIGSTORF, W. and SCHWARTZ, A. M. (1986), Legal Protection Insurance: American and European Approaches. Chicago: American Bar Foundation \& American Prepaid Legal Services Institute, 1986.

PFUNDT, K. (1985), Bedeutung und Charakteristik von Heim- und Freizeitunfällen (Mitteilungen der Beratungsstelle Schadenverhütung. Nr. 26). Köln: Verband der Haftpflichtversicherer, Unfallversicherer, Autoversicherer und Rechtsschutzversicherer e. V., 1985.

RIEGER, W. (1986), "No-fault" in Deutschland? Die Faszination ist geschwunden, in: ZVersWiss 1986, pp. 11-34.

RÖHL, K. F. (1983), Der gerichtliche Vergleich - Strukturierung des Themenbereichs, in: Der Prozessvergleich - Möglichkeiten, Grenzen, Forschungsperspektiven, pp. 11-34. Köln: Bundesministerium der Justiz, 1983.

ROTTLEUTHNER, H. (1985), Verfahrensflut und Verfahrensebbe, in: ZRP 1985, pp. 117-119.

ROTTLEUTHNER, H. and ROTTLEUTHNER-LUTTER, M. (1987), Zur Wirksamkeit der ZPOVereinfachungsnovelle, in: DRiZ 1987, pp. 139-144.

Rules Relating to Civil Liability connected with the carrying out of Dangerous Activities: Brief Comparative Law Survey prepared by the Unidroit Secretariat, in: 1982 II Uniform Law Rev. 333.

SANDEN, G. (1967), Schmerzensgeld und Haftpflichtnovelle, in: VersR 1967, pp. 413-420.

SCHIEMANN, G. (1981), Argumente und Prinzipien bei der Fortbildung des Schadensrechts - dargestellt an der Rechtsprechung des BGH (Münchner Universitätsschriften, Juristische Fakultät, Band 45). München: C. H. Beck, 1981.

SCHMEER, H. (1973), Haftungsersetzung durch Versicherungsschutz? in: VersR 1973, pp. 390-395.

SCHMIDT, R. (1987), Staatshaftung für Waldschäden, in: ZRP 1987, pp. 345-349.

SCHMIDT-SALZER, J. (1986a) Kommentar EG-Richtlinie Produkthaftung, Band 1, Deutschland. Heidelberg: Verlag Recht und Wirtschaft, 1986. 
SCHMIDT-SALZER, J. (1986b), Umwelt-Altlasten und Haftpflichtversicherung, oder: Das übersehene Risiko, in: Betriebsberater 1986, pp. 605-612.

SCHULIN, B. (1981), Soziale Entschädigung als Teilsystem kollektiven Schadensausgleichs. Köln: Heymann, 1981.

SCHWARTING, H. (1986), Die Schadenstragung als Quasi-Versicherer: Zum Eindringen von Versicherung und Versicherungsgedanken in das Haftungsrecht (Veröffentlichungen des Instituts für Versicherungswissenschaft der Universität Mannheim, No. 29). Karlsruhe: Verlag Versicherungswirtschaft, 1986.

STÜRMER, U. (1987), Claims Handling and Investigation: A Foreign Insurer's View of American Tort Litigation. Paper delivered at the Annual Meeting of the American Bar Association, Section of Tort and Insurance Practice, San Francisco, August 11, 1987.

STURNER, R. (1984), Zur Gerechtigkeit richterlicher Schadenszuweisung, in: VersR 1984, pp. 297-308.

STÜRNER, R. (1986), Der Unfall im Straßenverkehr und der Umfang des Schadenersatzes unter besonderer Berücksichtigung des Nichtvermögensschadens, in: DAR 1986, pp. 7-12.

WEYERS, G. and OBERHAUSER, A. (1984), Kumulationsabbau bei den Sozialleistungen. Berlin: Duncker \& Humblot, 1984.

WEYERS, H.-L. (1971) Unfallschäden: Praxis und Ziele von Haftpflicht- und Versorgungssystemen. Frankfurt a. M.: Athenäum, 1971.

WEYERS, H.-L. (1977), Perspektiven für das Unfallschadensrecht, in: ZRP 1977, S. 292-295.

WILL, M. R. (1980), Quellen erhöhter Gefahr (Münchener Universitätsschriften, Reihe der Juristischen Fakultät, No. 42) München: C. H. Beck 1980.

ZWEIGERT, K. and KÖTZ, H. (1966), Die Haftung für gefährliche Anlagen in den EWG-Staaten sowie in England und in den Vereinigten Staaten von Amerika. 1966. 